\title{
Motives of watching drama series online among Egyptian youth \\ Multi-method Approach
}

\section{Mai Magdy Abo Al Saoud}

Lecturer Assistant at Broadcasting Department, Faculty of Mass Communication, Modern Sciences and Arts

University . Cairo Egypt

\section{Introduction}

Web drama began to appear in mid 1990s' and rapidly spread in the past ten years in USA and UK. One of the most successful web drama experiences till today is "Lonely Girl 15". This series is about a teenage girl who speaks about her daily problems through a web camera. At the end of the series, there were more than 100 million people viewing the last webisode. However, the first web drama in the Arab world showed up in 2009. It is a Lebanese web series called "Shankaboot", and it is in Lebanese dialect. Later, two Lebanese web series came up called "Beirut... I love you, I love you not" and "Mamnou'u". Lately, "Fasateen", a Lebanese web series, burst out on the online arena. 
In the Arab world, the real reason for web drama to show up is Arab spring revolutions and political movements in the Arab street, since these fluctuations promote and support the freedom of expression and speech. There were some small efforts of web drama experiences in the Arab region in Saudi Arabia, Jordan, Morocco, and Egypt. Meanwhile, Lebanon was a pioneer in this sector and produced four web drama series. Most web drama series attract youth away from TV channels due to its simplicity in presenting as well as tackling their problems and treating social issues using comedy. Lately, the tendency of Arabic market, especially Middle East and North Africa, is in inclination to accept webisodes. Online audiences, mostly youth, are watching huge video content and are increasing in number. According to Ghannam (2011), Shankaboot has attracted 160,000 viewers on YouTube. Such display platforms will persist to capture viewers across the area reaching over 351 million Arab.

Web drama is very distinctive from other types of drama series. It has a different style of script writing. In addition, almost all video shooting is outdoor, and indoor décor can be limited to a room. It is a low budget production as usually actors are beginners. The duration of one-webisode ranges from 3-10 minutes and the video shooting may involve a lot of handy camera. Web drama cannot be broadcasted on TV but streamed online as it is tailored for the web. It is streamed through YouTube and video streaming sites (VSS) like Shahd. net. The viewer does not have to follow the series from the beginning as each webisode has a different theme. Also, web drama does not need a license to be streamed online and evades from censorship.

\section{Importance of Research}

- Drama series online consist of two categories; the first category is TV drama series streamed online, and the second category is web drama, which is an interactive narrative drama that involves very high level of audience interactivity and audience engagement.

- The importance of this idea lies in what is called 'Internet era'. Today, there is the web TV that enables Internet users or viewers to watch TV shows, football matches, films, TV drama, as well as web drama. That's why it is useful to meditate the exploitation of the horizon that Internet gives to develop new drama, make stories, and create chain of interesting and exciting characters that attract audience to it.

- Being the first of its kind to handle the study of such a drama in the Arab world, this research adds new and rich information about web drama.

- Hopefully, this study will be useful for all who work in drama and especially for young web drama producers to encourage and motivate them to experience such an innovative and creative endeavor in this field. This study is going to be an index that indicates how much are the audience satisfied by this drama. This is done through knowing the audience's preferences and concerns.

- This research is significant as it is crucial to study why there is a high percentage of 
المجلة العربية لبحوث الاعلام والاتصال - : العدد عץ - يناير / مارس - 19.r

Egyptian youth watching drama online, to explore the main reasons behind this new phenomena, and to know the way web drama is disseminating via Internet.

\section{Literature Review}

Studies concerned with "interactive narrative drama" (Shankaboot):

At the beginning, the idea of web drama in the Arab world came up when BBC made a competition about story writing for young Arab writers with age range (16-25) in 2009. It was an invitation to young writers to propose their thoughts, and then a small group was chosen to join a storytelling workshop in Lebanon. The result of this workshop was Shankaboot (a Lebanese word that means motorbike). Concerning the Arab world, the aim was to invent a new and stimulating drama especially tailored for Arab youth. It has been known that web drama continues to be intact zone in the Arab region ("Online Drama", 2009).

"Shankaboot" was launched on March 2010. It is about Suleiman, a 15 years old delivery boy, who is meandering in Beirut streets and wandering its districts using his scooter that is called "Shankaboot". Accidentally, Suleiman meets Ruwaida, a young pretty woman fantasizing of becoming a famous singer. She escaped from her fierce husband. Then, Suleiman's friend Chadi got him into a misfortune. It won the reflet d'Or at the Cinema Tous Ecrans festival in Geneva in November 2010 for best web series. In 2011, it won the international digital Emmy for the best digital fiction program (Badine, 2011).
As for interactivity, "Shankaboot's" audience will be mainly liable for forming the second season thus being Shankactive. Being Shankactive means audience is able to comment, share, and post clips of the webisode. Also audience can get involved in writing the last webisode or vote for a particular ending through a poll. Active audiences are involved in which there are operating narrative production and digital audiovisual projects workshops for youth ("Web Drama Shankaboot", 2012).

\section{Cyber drama:}

"Al Mahkama" is the first Egyptian web series created in 2012 and produced by El GTV (Internet TV). Shady Sherif, the owner of El GTV, wanted to create online media content in which audience interacts with it. "El Mahkama" is written by Karim Fahmy and directed by Mohamed Shaker. It is called "El Mahkama" (The Court) inferring to that the audience is the judge. "El Mahkama" is about a prosecutor who investigates in a group of mysterious cases. The prosecutor looks for the criminal and leaves the whole puzzle to the audience in order to solve the enigma via the clues. "El Mahkama" focuses on handling social issues. The first season consisted of 7 webisodes that are streamed weekly. Each webisode is 7 minutes. The audience gets engaged by choosing the criminal from the 3 suspects whom they appear on the screen by the end of each webisode and mention the clue. The winner gets a valuable prize like iPod, PlayStation, or mobile phone (El Sharqawy, 2012). 


\section{Digital Storytelling:}

According to Jennes, Pierson, and Broeck (2014), the web users are empowered, as they can interact with the media content, express themselves, and be creative to an extent that they make their own audience. The users get control over their media experiences. They decide what to watch, when, and where. Now, audience can attain different roles like aggregation of content and production that used to be the special realm of media corporations and production businesses. Social networks offer Internet users a display place for bulk self-communication, content aggregation, and user generated content dissemination. The purpose of such a display place is not to give power to the web users but to trade their own information. It is important to observe to what range Internet can substitute TV.

\section{Theoretical Framework \\ Diffusion of Innovation:}

Diffusion of Innovation theory is used in this research to show how watching drama series online, especially web drama, is disseminating as a new concept of trans-media starting from innovators, going through all stages, and reaching laggards. Diffusion of innovation examines in what way the social mechanism of an innovation is recognized and disseminated throughout the social scheme. This theory's major focus is the stage of adoption or refusal of an innovation. The basics of diffusion of innovation are the innovation mediums in which communication goes through and associates adopter categories and time.
Referring to stages of innovation decision process, there are mass media and interpersonal communication mediums in which channels of mass media are vital in the knowledge stage because it disperses information quickly and alters feeble attitudes.

\section{Uses and Gratifications:}

Accordingly, it is the acknowledgment of the needs and wants, thus motives, of Egyptian youth, which are fulfilled when watching drama series online. Gratifications, in general, are when people satisfy their own needs like studying, amusing, socializing, and understanding their personal assimilation and diversion. However, the uses include wasting leisure time and using Internet because of habituation, which can cause addiction. Sometimes people are selective and lucid or loosen and divert when choosing a certain media content. So, uses and gratifications theory is valuable as it accommodates in comprehending how and why these motives of individuals are exploiting Internet and other computer technologies.

\section{Research Problem}

The research problem is about noticing an increase in the percentage of audience watching drama online in which the number of viewers for the $1{ }^{\text {st }}$ webisode of "Shankaboot" is 99,785 viewers since it was posted on (YouTube) on 11-03-2010 till 10-11-2013. Also, the number of viewers for the last episode of the TV drama "Sabq Al Asrar" is 72,418 viewers since it was posted on (YouTube) on 9-07-2013 till 10-112013. 
المجلة العربية لبحوث الاعلام والاتصال - : العدد عץ - يناير / مارس - 19.r

The problem is worth studying since there is a high rate of exposure and audience watching drama online that might create a challenge to TV drama series. In other words, it is going to reveal the reasons behind the increase in the percentage of audience watching drama online and also discover to what degree watching drama online affects Egyptian youth and satisfies their needs. The target audience of watching drama online is young people who are familiar with the use of technology and Internet that became part of their daily lives. Young people are highly affected by this drama as they are in the adolescence stage in which their needs are fulfilled.

\section{The Objectives}

1. To recognize the advantages of watching drama series online.

2. To identify the uses and gratification of Egyptian youth towards watching drama series online (TV drama and web drama).

3. To acknowledge the motives of watching drama series online among Egyptian youth.

\section{Hypotheses}

H1: The higher the audience's innovativeness, the more likely they are to adopt watching online drama.

$\mathrm{H} 2$ : Watching online drama has a negative effect on watching TV.

H3: There is a positive relationship between watching online drama and encouraging the use of online media.

\section{Research Questions}

RQ1: What are the motives of Egyptian Youth towards watching drama series online? RQ2: What are the socio-psychological impacts of watching online drama on Egyptian youth?

\section{Methodology \\ Quantitative Approach \\ Method: Survey}

Descriptive survey is used because it describes or manuscripts present situations in order to justify what exist on the spot. In addition, this approach will show more exact results and uses to supplement other techniques like FGDs and in-depth interviews. The questionnaire was conducted on May 2015.

\section{Questionnaire Description:}

The structure of the questions was based on the answers of the participants in FGDs and inspired by the results of FGDs. Question no. 9 is about innovativeness and involves Likert scale. Statements were taken from the innovativeness scale that was used in FGDs. The questionnaire consists of 19 questions.

\section{Population and Sample Sampling:}

A survey is used in which a questionnaire is conducted on a sample of 400 university students that is 200 males and 200 females. The age range is $18-25$. The sample is divided equally between public university (Cairo University) and private university (MSA University). 


\section{Results}

Table (1)

Statements of innovation scale

\begin{tabular}{|c|c|c|c|c|c|c|c|c|c|c|c|c|c|}
\hline \multirow{2}{*}{ Degree } & \multicolumn{2}{|c|}{$\begin{array}{c}\text { Strongly } \\
\text { Agree }\end{array}$} & \multicolumn{2}{|c|}{ Agree } & \multicolumn{2}{|c|}{ Neutral } & \multicolumn{2}{|c|}{ Disagree } & \multicolumn{2}{|c|}{$\begin{array}{l}\text { Strongly } \\
\text { Disagree }\end{array}$} & \multirow{2}{*}{ Mean } & \multirow{2}{*}{$\begin{array}{c}\text { Std. } \\
\text { Deviation }\end{array}$} & \multirow{2}{*}{$\begin{array}{l}\text { Relative } \\
\text { Weight }\end{array}$} \\
\hline & $\mathrm{N}$ & $\%$ & $\mathrm{~N}$ & $\%$ & $\mathrm{~N}$ & $\%$ & $\mathrm{~N}$ & $\%$ & $\mathrm{~N}$ & $\%$ & & & \\
\hline $\begin{array}{l}\text { 1-I enjoy } \\
\text { trying new } \\
\text { ideas }\end{array}$ & 202 & 50.5 & 149 & 37.3 & 35 & 8.8 & 9 & 2.3 & 5 & 1.3 & 4.34 & 0.83 & 86.70 \\
\hline $\begin{array}{l}\text { 2- I am } \\
\text { suspicious } \\
\text { of new } \\
\text { inventions } \\
\& \text { new ways } \\
\text { of thinking }\end{array}$ & 24 & 6.0 & 68 & 17.0 & 130 & 32.5 & 115 & 28.8 & 63 & 15.8 & 2.69 & 1.11 & 53.75 \\
\hline $\begin{array}{l}\text { 3- I seek out } \\
\text { new ways to } \\
\text { do things }\end{array}$ & 163 & 40.8 & 151 & 37.8 & 70 & 17.5 & 8 & 2.0 & 8 & 2.0 & 4.13 & 0.91 & 82.65 \\
\hline $\begin{array}{l}\text { 4- I rarely } \\
\text { trust new } \\
\text { ideas until I } \\
\text { can see } \\
\text { whether the } \\
\text { vast } \\
\text { majority of } \\
\text { people } \\
\text { around me } \\
\text { accept them }\end{array}$ & 45 & 11.3 & 92 & 23.0 & 105 & 26.3 & 100 & 25.0 & 58 & 14.5 & 2.92 & 1.23 & 58.30 \\
\hline $\begin{array}{l}\text { 5- I feel that } \\
\text { I am an } \\
\text { influential } \\
\text { member of } \\
\text { my peer } \\
\text { group }\end{array}$ & 69 & 17.3 & 23.5 & 94.0 & 193 & 48.3 & 32 & 8.0 & 12 & 3.0 & 3.44 & 0.97 & 68.80 \\
\hline $\begin{array}{l}6 \text { - I am } \\
\text { hesitant } \\
\text { about } \\
\text { adopting } \\
\text { new ways of } \\
\text { doing things } \\
\text { until I see } \\
\text { them } \\
\text { working for } \\
\text { people } \\
\text { around me }\end{array}$ & 30 & 7.5 & 86 & 21.5 & 94 & 23.5 & 110 & 27.5 & 80 & 20.0 & 2.69 & 1.22 & 53.80 \\
\hline $\begin{array}{c}\text { Number of } \\
\text { Subjects } \\
\text { had been } \\
\text { asked }\end{array}$ & & & & & 1 & & & & & & & & \\
\hline
\end{tabular}


Students were asked about innovation, and they were required to refer to each statement with a degree from 1-5 in which 5 is the strongest agree, 4 - agree, 3 - neutral, 2 - disagree and 1 strongly disagree. Results showed that the most statement students agree to in terms of relative weight is "I enjoy trying new ideas" then "I seek out new ways to do things". At the third place comes "I feel that I am influential member of my peer group" then "I rarely trust new ideas until I can see whether the vast majority of people around me accept them". "I am hesitant about adopting new ways of doing things until I see them working for people around me" is no. 5. Finally, "I am suspicious of new inventions and new ways of thinking" comes at the end.

Table (2) - Have you heard of Web Drama?

\begin{tabular}{|c|c|c|c|c|c|c|c|c|c|}
\hline \multicolumn{2}{|c|}{ Demographics } & \multicolumn{2}{|c|}{ Gender } & \multicolumn{2}{|c|}{ University } & \multicolumn{3}{|c|}{ SES } & \multirow{2}{*}{ Total } \\
\hline & & Males & Females & Public & Private & Low & Medium & High & \\
\hline \multirow[t]{2}{*}{ Yes } & $\mathrm{N}$ & (63) & $(60)$ & (52) & (71) & (20) & (72) & (31) & (123) \\
\hline & $\%$ & 31.5 & 30.0 & 26.0 & 35.5 & 27.4 & 33.2 & 28.2 & 30.8 \\
\hline \multirow[t]{2}{*}{ No } & $\mathrm{N}$ & (137) & (140) & (148) & (129) & (53) & (145) & (79) & (277) \\
\hline & $\%$ & 68.5 & 70.0 & 74.0 & 64.5 & 72.6 & 66.8 & 71.8 & 69.3 \\
\hline \multirow[t]{2}{*}{ Total } & $\mathrm{N}$ & (200) & (200) & (200) & (200) & (73) & (217) & (110) & $(400)$ \\
\hline & $\%$ & 100.0 & 100.0 & 100.0 & 100.0 & 100.0 & 100.0 & 100.0 & 100.0 \\
\hline \multicolumn{2}{|c|}{ Chi-Square } & \multicolumn{2}{|c|}{$\begin{array}{c}\text { Pearson Chi- } \\
\text { Square }= \\
0.106 \\
\text { Df }=1 \\
\text { Phi factor }= \\
0.016 \\
\text { Sig }=0.745\end{array}$} & \multicolumn{2}{|c|}{$\begin{array}{c}\text { Pearson Chi- } \\
\text { Square }= \\
4.238 \\
\text { Df }=1 \\
\text { Phi factor }= \\
0.103 \\
\text { Sig }=0.040 \text { * }\end{array}$} & \multicolumn{3}{|c|}{$\begin{array}{c}\text { Pearson Chi-Square } \\
=1.328 \\
\text { Df }=2 \\
\text { Contingency } \\
\text { Coefficient }=0.058 \\
\text { Sig }=0.515\end{array}$} & \\
\hline
\end{tabular}

$* \mathrm{P}<0.05, \mathrm{X}^{2}=4.2$

Students were asked about their awareness of web drama. No significant differences were found except for university. Interestingly, total of $(69.25 \%, \mathrm{n}=277)$ for students in public and private universities stated no. Therefore, they never heard of web drama. It is worth to mention that $(35.5 \%, \mathrm{n}=71)$ of students in private university stated yes, so they are aware of web drama's existence. On the contrary, $(26 \%, \mathrm{n}=52)$ of students in public university know about web drama.

Table (3) - Perceiving the term 'Web Drama'

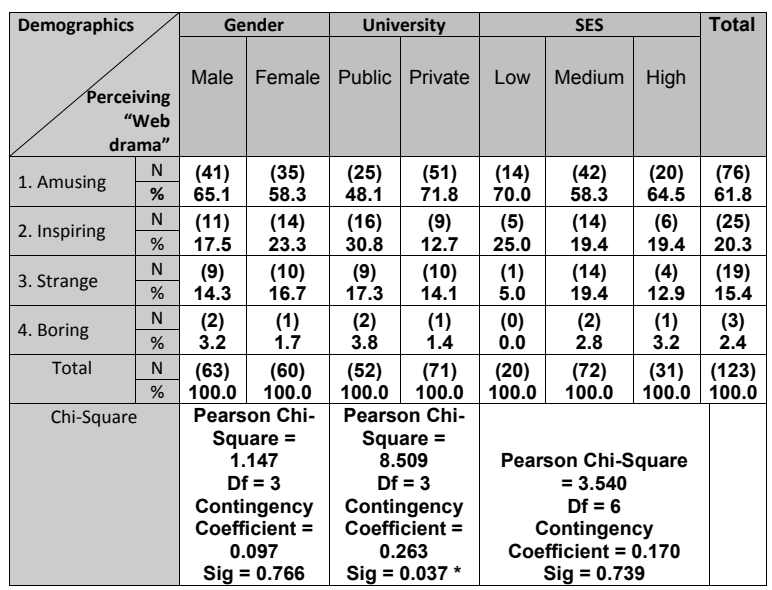

$* \mathbf{P}<0.05, \mathrm{X}^{2}=8.5$

Students were asked about how they perceive the term web drama. No significant differences were found except for university. Students in private university stated that they perceive web drama as an amusing content $(71.8 \%, \mathrm{n}=51)$ compared with students in public university scoring $(48.1 \%, \mathrm{n}=25)$. Consequently, the highest perception about web drama is amusing, scoring total of $(61.8 \%, n=76)$. Students in public university stated that they perceive web drama as an inspiring content $(30.8 \%, \mathrm{n}=16)$ compared with students in private university scoring $(12.7 \%, \mathrm{n}=9)$. The total of students perceive web drama as strange content in both 
universities is $(15.4 \%, \mathrm{n}=19) .(2.4 \%, \mathrm{n}=3)$ is the total of students in private and public universities perceive web drama as boring content.

\section{Results of Examining the Hypotheses}

H1: The higher the audience's innovativeness, the more likely they are to adopt watching online drama.

Table (4)

The intensity of watching the series through the Internet

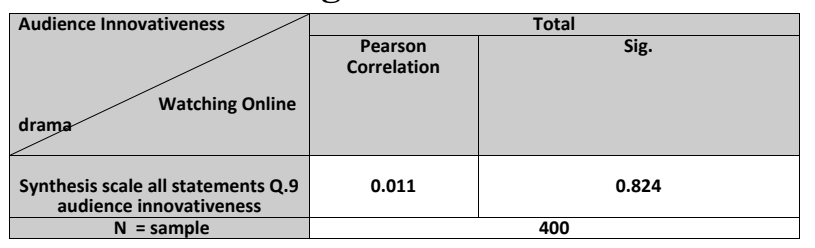

Linear correlation

Synthesis scale for all statements - audience's innovativeness

Students were asked about innovation, and they were required to refer to each of the six statements with a degree from 1-5 in which 5 is the strongest agree, 4 - agree, 3 - neutral, 2 - disagree and 1 - strongly disagree. There is a weak correlation between audience's innovativeness and adoption of watching online drama. In relation to diffusion of innovation theory, through all statements, only one statement showed statistical significance of 0.042 that is "I am hesitant about adopting new ways of doing things until I see them working for people around me". This means that students do not adopt watching online until they see others adopt watching online drama series. Therefore, students are categorized as early majority in the adopter categories (diffusion of innovation). This is confirmation of what came in the results of FGDs concerning TV drama series. Correspondingly, the most favorable number of hours for both males and females is 1-3 hours (neutral), scoring total of $(34.5 \%$, $\mathrm{n}=138$ ). Direct proportionately is when the innovativeness level is higher; number of hours would increase to 3-5 hours or 5 hours and more. $\mathrm{H} 1$ is proved not to be valid because the total of all statements doesn't show statistical significance.

The following table is concluded according to the statistical analysis of audience's innovativeness and adoption of watching online drama. The correlation is more illustrated in the table below:

Table (5)

Audience's innovativeness and adoption of watching online drama

\begin{tabular}{|l|l|l|}
\hline Number of Hours & Innovativeness Level & Adopter Categories \\
\hline Less than one hour & Very low & Laggards \\
\hline 1 hour & Low & Late majority \\
\hline $1-3$ hours & Neutral & Early majority \\
\hline $3-5$ hours & High & Early adopters \\
\hline 5 hours and more & Very high & Innovators \\
\hline
\end{tabular}


المجلة العربية لبحوث الاعلام والاتصال - : العدد عץ - يناير / مارس - 19 ب

H2: Watching online drama has a negative effect on watching TV.

Table (6)

The Relation between Watching Online Drama and Watching TV

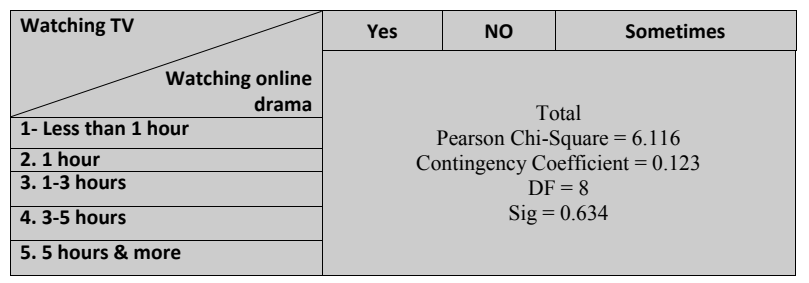

There is no relationship between watching online drama and watching TV. Data in the former table indicates that there is no statistical significance between watching online drama and watching TV. Watching online drama doesn't really affect watching TV. Still, students watch $\mathrm{TV}$; the content they watch mostly is movies and drama series, and least is TV shows in addition to football matches. However, they watch drama series online but in different timing and do not affect time dedicated for TV. This finding is dissonant with previous research finding of Yang and Olmsted (2009) that proved correlation between time dedicated to watch TV and web video watching since the emerge of online streaming platforms. This correlation proved that there is a fall in TV watching since webcasting online video began. $\mathrm{H} 2$ is not supported.

This is because youth in the west already depends heavily on Internet regarding almost everything like banking, shopping, online education and research, reading books and press, online gaming, making reservations, downloading and uploading content, and streaming video content like shows, drama series, movies, and football matches.

Comparatively, Egyptian youth don't depend on the Internet that much and mostly use Internet for entertainment like listening to music and radio and watch some online media content. Psychologically, they consider TV as a major device at home or wherever. Therefore, web video watching in Egypt unlike the west didn't affect TV watching. This point is more deliberated later in the discussion section.

H3: There is a positive relationship between watching online drama and encouraging the use of online media.

Table (7)

The Relation between Watching Online Drama and Encouraging the Use of Online Media

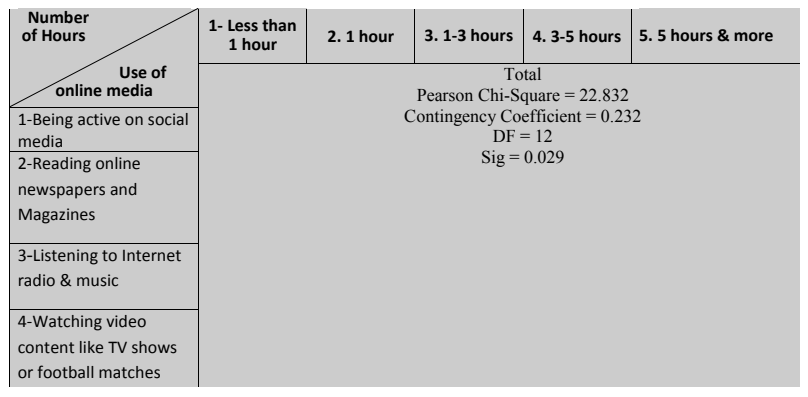

There is a positive relationship between watching online drama and encouraging the use of online media. In relation to uses and gratification theory, the action of being active on social media increases as the number of 
hours increases reaching frequency of 66 in 1-3 hours which is the most favorable number of hours then starts to decrease as the viewer is involved in watching long content for some time. Reading online newspapers and magazines increases with up to an hour then decreases with the increase of number of hours and reach steadiness, thus frequency $=3$. The peak occurs in the hour duration as reading for more than one hour can be discomforting and because reading needs more cognitive effort. Little activity continues perhaps because someone is looking for certain information or studying.

Listening to Internet radio and music increases as the number of hours increases reaching frequency of 43 in $1-3$ hours then starts to decrease to become steady as the user might be involved with other task. Watching video content like TV shows or football matches increases with up to an hour then decreases with the increase of number of hours and reaches steadiness, thus frequency $=7$. The peak occurs in the hour duration, as it is the appropriate duration for watching content. Little activity continues perhaps because there are some who might have a lot of leisure time to waste. H3 is proved to be valid.

\section{Research Questions}

RQ1: What are the motives of Egyptian youth towards watching drama series online?

Students were also asked to state why they watch TV drama series online. No significant differences were found except for one motive that is "to watch content without censorship" in which males scored $(16.5 \%, \mathrm{n}=33)$ compared to females who scored $(9 \%, \mathrm{n}=18)$. This is might be because males are more curious than females regarding censored scenes like obscene, religious, or political scenes. For females, it might be interpreted according to psychology in which "to watch content without censorship" is psychologically a hidden motive, but females don't express it because of society's norms and traditions. Other reason was spotted in the "other, please mention" but with little score is "content not broadcasted on TV" scoring $(0.8 \%$, $\mathrm{n}=3$ ). It is worth to be mentioned that another motive is that the series is webcasted online by HBO an American cable channel.

As for university, no significant differences were found except for motives like "to watch content for free", "to watch content without censorship", and "less ads or lack of ads". Importantly, more than half of the sample stated that less ads or lack of ads is a major motive for students to watch TV drama series online scoring $(82.8 \%, n=331)$. "To watch content for free" is an interesting finding that scored $21 \%$ of students in private (MSA university) versus only $7.5 \%$ of students in public (Cairo university). It implies that students in universities care about whether the content is free or not. Even if the student can afford to watch the content, still he or she looks for free content, as it is human nature to go after "free things". "To watch content without censorship" comes with total of $(12.8 \%, \mathrm{n}=51)$.

Referring to socio-economic status, no significant differences were found among different SES (socio-economic status) levels. In addition to the past motives, there are motives 
المجلة العربية لبحوث الاعلام والاتصال - : العدد عץ - يناير / مارس - 19 ب

with high frequencies like "to watch at the time of my choice" scoring total of $n=306$ and "to watch several episodes in row" reaching total of $\mathrm{n}=217$. "Wide variety of online drama series" comes at the third place with total of $n=105$. At the end, "for its convenient facilities" scores total of $n=76$.

RQ2: What are the socio-psychological impacts of watching online drama on Egyptian youth?

It is notable that students are interested in themes like social matters and human interest, which implies that they are socially and psychologically influenced by these themes since it affects their daily lives intimately.

\section{Discussion}

Theoretically, diffusion of innovation and uses and gratification theory are creating the framework of the research. There are statistically significant differences between respondents according to their demographic characteristics (Gender, socio-economic status - SES and university). One of the reasons or motives for watching TV drama series online is interaction and participation. Regarding this motive, low SES students scored the highest $13.7 \%$ compared to medium SES students 5.1\% and high SES students $7.3 \%$. This implies that high SES is not a predictor of new technology adoption. Through the survey, it shows that low SES students have a little progressive modernism level than medium and high SES students, as they interact and participate more than them principally on running after upcoming technological smart devices, which facilitates the use of social media. Although high SES students can afford such products, they don't buy it since it might not be tailored to their needs. Latest gadgets don't necessarily mean a complete satisfaction of needs and wants. Usually high SES students are well educated about technology and aware of its health risks.

The reason behind this is that low SES might suffer from less education towards technology and so just focuses on buying and possessing the latest portable devices and are highly grabbed by it. A similar finding has been previously proved in the study of Yang and Olmsted (2009) via survey. Its sampling is based on college students, which stated that non-adopters of web video boards and video downloading had a little enhanced innovativeness level than adopters, chiefly on meddling about future products. Non-adopters can be who cannot afford Internet or buying gadgets, or are not familiar with the use of technology.

Referring to the results of Likert scale used to measure innovativeness in the questionnaire in terms of relative weight, "I enjoy trying new ideas" is the most agreed to statement followed by "I seek out new ways to do things" and "I feel that I am influential member of my peer group". Statements with words like rarely, hesitant, and suspicious started taking the fourth, fifth, and sixth place. However, when examining the actual result of proving a correlation with the rate of watching TV drama series online, it turns out that there is only one statement that showed statistical significance with the rate of watching that is "I am hesitant about adopting new ways of doing things until I see them working for 
people around me". This signifies that subjects like to appear that they are acknowledged, aware, and confident of what they are doing or saying.

The result of the survey demonstrates that 277 of students in public and private universities never heard of web drama. This means that more than half of the sample doesn't know about web drama. This is because web drama is not disseminating particularly in the Arab world. Reasons of web drama not disseminating are weak Internet infrastructure, technological problems, pricey cost of Internet, financial problems, lack of marketing, scarce resources, advertising, and even mentioning it in academic education, and, above all, the need of skilled crew including scriptwriter, director, producer, etc....specialized in making web drama. As long as these elements or settings are not available to build a suitable environment for the web drama to exist and to have its market, it will never be an attractive media product or material for audiences or even investors. $61.8 \%$ of students in private and public universities stated that they perceive the term "web drama" as an amusing content. This suggests that more than half of the sample does admire it. So, creation of web drama in the Arab world or Egypt needs a push, more marketing and advertising, or sponsoring in order to grow and flourish.

Concerning watching entertainment content through $\mathbf{T V}$, results showed that $14 \%$ of students in private and public universities don't watch TV, $52 \%$ of students do watch $\mathrm{TV}$, and $34 \%$ of students sometimes watch TV. This evidence indicates that TV has a huge presence, is accessible everywhere, gets advertising, broadcasts powerful content, has a lot of employees, has a political and cultural influence, and is recognized by a great number of audience. Still, TV is the original device and therefore considered a threat to new media like web drama.

Comparatively, in Egypt, TV as a medium is not affected by web video watching (watching online drama) as mentioned in hypothesis 2 testing. In the west, TV is affected by online video watching. As stated in the study of Stasny (2011), number of people satisfied with watching TV on the Internet on a scale of 1 to 5,5 being the most satisfied is 29 people said 4. Also, number of people view media online is 66 , and 30 people view traditional media. In another study of Cha (2009), the time interval spent on viewing videos done by amateurs and consuming video sharing sites like YouTube declines the time interval spent on TV. In addition, the percentage of users who believe that the total time spent watching TV has fall is increasing from $15 \%$ in 2006 to $17.8 \%$ in 2009. According to Yang and Olmsted (2009), $45 \%$ of users stated that there is a fall in TV watching. This is because US enjoys new media technology and new media literacy. They have good Internet infrastructure and they are familiar with the use of online technology, devices, and computer. Also, they already have the language. However, users in Egypt who may suffer from electricity cut, weak Internet infrastructure, and high cost of Internet. The majority are not new media literate.

As for preference, 331 students stated that they 
المجلة العربية لبحوث الاعلام والاتصال - : العدد عץ - يناير / مارس - 19 ب

prefer watching drama series through TV. 69 students stated that they prefer watching drama series via Internet. Again, the actual reasons for this result are already mentioned above. Moreover, in Egypt it has been observed that the society greatly suffer from digital divide in which some people are not new media literate and others are. This might be because some live in rural areas and others live in urban ones. There is a generation that has been raised upon traditional media like TV, and a new generation that is basically raised on technology, computer, Internet, and smart gadgets like tablets, smartphones etc.. Nowadays, the supply of smart portable devices is high, so these devices are becoming cheap compared to old days.

About the future of Internet and TV, $45.3 \%$ of students stated that Internet is a supplementary or complementary companion for TV. $29.5 \%$ of students believe that Internet substitutes TV. $25.3 \%$ of students think that TV and Internet will merge together like smart TV. Currently, youth prefer Internet to TV, as web becomes a substitute display for entertainment.

Considering Internet as a complementary companion for $\mathbf{T V}$, it is the real role of Internet to pair with TV despite of the other functions of Internet. Naturally, this statement achieves the highest percentage. Every TV show, drama series, movie, or any content has a Facebook, twitter, YouTube, Instagram, and snap chat accounts. Interaction and participation occur via social media provided by the Internet. Since audience interaction and participation are important nowadays to media corporations, it helps in increasing the rate of watching. Also, each broadcast network has its own website, which is not a preferred platform for audience or online users to watch online content as mentioned in Vorhaus (2008). In contrary, online streaming platforms are more preferred as its servers are specialized for loading or buffering content.

As for substitution, $29.5 \%$ of students stated that Internet substitutes TV counter to the finding of the study Yang and Olmsted (2009), which stated $61 \%$ of audiences concur that online video platforms are substituting watching TV. This is because audiences in the west use Internet TV extensively that we lack. $25.3 \%$ of students think that the future is smart TV (Internet and TV combined). It is scoring the least percentage of all three states denoting that smart TV is an expensive device and not everyone can afford it in evidence that it did not spread up till now although it has been in the market for some time. Some electronic companies are trying to manufacture the same concept of smart TV but with cheaper technology.

A key finding is that there is a study, which particularly has the similar theoretical framework as this research paper. It is (Alternative Platforms and the Audience: Exploring the Predictors in the Audience's Adoption of Online Media Platforms). The common result between both studies is that generally, youth have a high innovativeness level. Using survey, Yang and Olmsted (2009), stated that audience innovativeness is not predictive of new platform adoption, and the benefits of web video platforms are significant predictor of audience's adoption of new 
platforms. This research paper's results varies or differs from that study in which audience innovativeness is a vital predictor and is positively related or directly proportional with the adoption of watching drama series online. Even if the benefits of certain new medium is the predictor of such adoption, the individual must enjoy or have a particular level of innovativeness especially that this person will have to use technology to practice a behavior like watching web videos on new platforms or watching drama series online. This is because of digital divide's existence in Egypt.

\section{Conclusion}

To sum up, the most favorable number of hours spent for watching online drama for males and females is 1-3 hours. Although, the American and Arabic drama series score the highest records, females favor Turkish drama series. For males, the most watched genre is action. While for females, the most watched genre is romance. The most watched genre for males and females is comedy. Adventurous and science fiction genres score good premium. The most interesting themes are social matters and human interest. For males and females, the most attractive features in drama series are idea, actors and actresses, and conflict; in addition, dialogue scores good premium.

The main motives of Egyptian youth towards watching drama series online are to watch content without censorship and to watch content for free and less ads or lack of ads. In Vorhaus (2008), 8\% of web video audiences state that ads are more tolerable online than on
TV. Also, there is a convenient option, "skip ad", which the viewer can use. Advertising is a main source of revenues in TV and most of the media institutions have to find a solution for the alternative revenue of watching drama series online.

Apparently, these results imply that the advantages of online streaming platforms are significant predictor of youth's adoption of new platforms. Consequently, the more youth take into account the advantages obtained from using online platforms, the more the probability of them adopting new platforms increases. This is what the study of Yang and Olmsted (2009) assured. In addition, it states that these benefits, which are important results, include relative advantage, compatibility, complexity, trialability, and observability. In Cha (2009), what boost the relative advantage of using web video platforms are storage capability, interactivity, and quality of video content. This means that creators of online platforms have to consider these benefits when creating new platforms and to pay attention to two factors that are time and cash, in which the content has to be short and cheap. In this way, platforms will be attractive to the audiences especially youth.

The ritualized motive of Egyptian youth towards watching online drama is that drama series are not available anywhere else but online. It turns out that youth's gratifications are entertainment, social interaction, learning, and escape through emotional mood. In terms of centennial weight, entertainment, which is a para-orientational gratification, scores the highest. As mentioned in the study of Yang 
المجلة العربية لبحوث الاعلام والاتصال - : العدد عץ - يناير / مارس - 19.r

and Olmsted (2009), audiences use online video more for amusement than searching for information then comes social interaction, which is social gratification. Learning (orientational gratification) takes the third place, and the least is escape through emotional mood thus parasocial gratification.

The biggest perception perceived by youth towards web drama is amusement. Watched web drama that were mentioned are almost equally divided in number between Arabic and English drama series. As for interactive narrative drama or web drama broadcasted on TV, good success is achieved, but when "Esteefa", the second interactive narrative drama to be broadcasted on TV (Ramadan 2015), was not recognized because it is the same idea as "Man El Gany", it assured the poor thinking of scriptwriters and weak style of writing. Now, it is all about using drama for commercial purposes.

Although youth started to watch online drama, it did not affect the time of watching TV. Still, they do mostly watch entertainment content like movies and drama series through TV. TV shows and football matches come after that. Youth prefer watching drama series through TV to Internet. The Ministry of Communication and Information Technology promised to improve Internet infrastructure by replacing copper wires with optical fiber cables, regulating prices of Internet, and increasing the broadband.

The most convenient gadget to be used among youth to watch online content is laptop. Watching online drama did encourage youth to use online media like being active on social media and listening to Internet radio and music. Reading newspapers and magazines and watching online videos like TV shows or football matches score low records. Concerning Internet and $\mathrm{TV}$, most students agree that Internet is a complementary companion for TV. Perhaps, youth with high socio-economic status want smart $\mathrm{TV}$, which is a device that merges Internet and TV together. However, others reveal that Internet substitutes $\mathrm{TV}$ because it might have a wide variety of drama series more than TV. Internet and TV can substitute each other. If there is no Internet connection, TV will be the alternative. As a matter of substitution, users might consume online platforms instead of TV.

The study of Cha (2009), states that substitution only cannot boost the dissemination of online streaming platforms. The bottom line is that compatibility is an advanced element for the intension to operate online streaming platforms and unwanted for the intension to operate TV. Compatibility is important especially at the early stages of diffusion. Internet, particularly online streaming platforms, is compatible more than TV because the user can choose the drama series he or she wants to watch, decide when to watch it, and download it as well.

At the end, there is no one with no innovativeness; everyone has a specific degree of innovativeness. According to diffusion of innovation theory, all people are adopters but in different categories, and this is because of the time factor. As proved in previous research, even non-adopters have an innovativeness level. Therefore, innovativeness is tough to be 
measured precisely as it is a concept and not a capacity. And in this research, when trying to measure innovativeness, intellect is measured as well as it is related to innovativeness. Innovativeness itself is not measured, as it is provisional but intellect since it is an attribute. Generally, students enjoy a level of innovativeness that makes it hard to distinguish the minor differences among them like place of birth (raising) or coming from foreign background. It is still unclear to articulate how long young people or students will continue to use web-streaming platforms regularly to watch online drama. Obviously, web-streaming platforms endure the distinctive stages of diffusion.

The limitation of this paper is that the sample is conducted only in Cairo, Egypt. The sample is nonrandom - purposive which means that results cannot be generalized. Its findings are applied only to young people, who watch drama series online, educated, computer literate, and familiar with online media. Another restrain in this study is the lack of Egyptian or Arabic academic studies concerning the topic of watching online drama series and web drama.

Now, the question that arises is that would the continuing development of smart devices, webcasting, social media, and new media as a whole push people to be new media adopter with certain level of innovativeness or people would abandon and move away from new media because such technologies have a massive impact on human psychology and health risks? It is difficult to answer this question as it embraces a lot of influencing factors. As a conclusion, perhaps the existed innovativeness scales used to measure audience innovativeness are reasonable, but still researchers must improve further advanced assessment on innovativeness to study carefully the correlation between innovativeness and audiences' adoption of new media. 
المجلة العربية لبحوث الاعلام والاتصال - : العدد عץ - يناير / مارس - 19 ب

\section{References}

1. Badine,C.P.(2011). Shankaboot, or the unprecedented success of a web drama in the Arab world. INA Global. Retrieved September 22,2013,from www.inaglobal.fr/en/digital-tech/ article/shankaboot-or-unprecedented-successweb-drama-arab-world

2. Cha, J. (2009). Television versus the Internet: a comparative analysis of traditional and new video platforms in substitutability, perceptions, and displacement effects. (Order No. 3496129, University of Florida). ProQuest Dissertations and Theses, 232-n/a. Retrieved October 4, 2014 from http://search.proquest. $\mathrm{com} /$ docview $/ 920022451$ ? accountid $=8423$. (920022451).

3. El Sharqawy,S.(2012).Al Mahkama.... the first Egyptian online drama. Al Sharq El Awsat Newspaper ASAA. Issue 12344. Retrieved November 15, 2013, from http://www.classic. aawsat.com/print.asp?did $=6951$

4. Ghannam, J. (2011). Social media in the Arab world: leading up to the uprisings of 2011. Centre for International Media Assistance. Retrieved June 3,2013, from http://www.edots. ps/internews/userfiles/CIMA-Arab_Social_ Media-Report_1.pdf

5. Jennes, $\overline{\mathrm{I}}$. and Pierson,J. and Van den Broeck,W. (2014).User empowerment and audience commodification in a commercial television context. The Journal of Media Innovations 1.1. (pp.71-87). 17p. University of Brussel. Retrieved October 30,2014,from http:// www.journals.uio.no/index.php/TJMI

6. (2009). Online drama. BBC world service trust. Retrieved January 15,2013,from www.bbc.co.uk
7. Stasny, W. M., Jr. (2011). An investigation into user acceptance of, and satisfaction with, digital media made available legally by media outlets. (Order No. 1499735, Kutztown University of Pennsylvania). ProQuest Dissertations and Theses, 71. Retrieved October 18, 2014 from http://search.proquest. com/docview/896612278? accountid $=8423$. (896612278).

8. Vorhaus, M. (2008). Online TV watching shift mostly due to convenience. Advertising Age. Vol.79. Issue 23. Retrieved September 6, 2013, from Ebscohost Library, Communication and Mass Media Complete database.

http://web.ebscohost.com/ehost/ detail?vid $=4 \&$ sid $=\mathrm{f} 455 \mathrm{c} 704-940 \mathrm{e}-4 \mathrm{bbe}-\mathrm{a} 95376$ 3 cfcc5e8e3\%40sessionmgr 198\&hid=1\&bdata= JnNpdGU9ZWhvc3QtbG12ZQ\%3d\%3d\#db=uf $h \& A N=32579019$

9. (2012). Web drama Shankaboot connects Arab youth. BBC Media Action. Retrieved October 20, 2014, from www.bbc.co.uk/ mediaaction/where_we_work/middle_east/ lebanon/shankaboot.html

10. Yang, Y. and Chan-Olmsted, S. (2009). Alternative platforms and the audience: exploring the predictors in the audience's adoption of online media platforms. University of Florida, International Communication Association. Retrieved September 22, 2013, from Ebscohost Library, Communication and Mass Media Complete database.

ht tp://web.ebscohost.com/ehost/ detail?vid $=4 \&$ sid $=$ f455c704-940e-4bbe-a 95376 3 cfcc5e8e3\%40sessionmgr 198\&hid $=127 \&$ bdat $a=J n N p d G U 9 Z W h v c 3 Q t b G 12 Z Q \% 3 d \% 3 d \# d b=$ ufh \&AN=45285900 
المجلة العربية لبحوث الاعلام والاتصال - : العدد عץ - يناير / مارس - 19 